\title{
10. PETROLOGY AND GEOCHEMISTRY OF BASALTS FROM DSDP LEG 34, NAZCA PLATE
}

\author{
Geoffrey Thompson and W.B. Bryan, Woods Hole Oceanographic Institution, Woods Hole, Massachusetts \\ and \\ F.A. Frey, J.S. Dickey, and C.J. Suen, Massachusetts Institute of Technology, Cambridge, Massachusetts
}

\begin{abstract}
Geochemical studies of basalts from Sites 319, 320, and 321 of Leg 34 indicate that in all cases they are large-ion-lithophile (LIL) depleted tholeiites typical of ocean floors; that is, they are depleted in light rare earth elements (LREE) relative to chondrites and have low abundances of $\mathrm{K}, \mathrm{Sr}, \mathrm{Ba}$, and $\mathrm{Zr}$ relative to island and continental basalts. Samples from Hole 319 and the upper cooling units of Hole 319A have $\mathrm{K}_{2} \mathrm{O}(0.4 \%)$ and $\mathrm{TiO}_{2}(1.17 \%)$ concentrations similar to those of tholeiitic basalts from the East Pacific Rise. Compared to these upper flow units, the lower units of Hole 319A have higher concentrations of elements such as $\mathrm{V}, \mathrm{Y}, \mathrm{Zr}, \mathrm{Sr}$, and $\mathrm{REE}$ and lower concentrations of $\mathrm{Ni}, \mathrm{Co}$, and $\mathrm{Cr}$. In Hole 320B the upper units are similar to the upper units of Hole 319. One lower unit in Core 5 of Hole $320 \mathrm{~B}$ is texturally and petrographically different and shows higher concentrations of elements such as $\mathrm{K}, \mathrm{Ti}, \mathrm{Fe}, \mathrm{V}, \mathrm{Y}, \mathrm{Zr}$ and lower concentrations of $\mathrm{Mg}, \mathrm{Cr}$, and Ni. Site 321 is similar in composition throughout. Compared to the other units, these basalts have higher concentrations of $\mathrm{Fe}, \mathrm{Ti}, \mathrm{Ba}, \mathrm{V}, \mathrm{Y}, \mathrm{Zr}$, and heavy REE (30X chondrite) and lower concentrations of $\mathrm{Mg}, \mathrm{Ni}$, and $\mathrm{Cr}$.

The geochemical and petrographic evidence is compatible with an origin of these flows at a spreading center. Major element compositional differences between flow units can be explained by shallow level fractional crystallization of plagioclase, clinopyroxene, and minor olivine. Although the compositional trends of most trace elements are consistent with the direction of fractionation indicated by the major elements, models based on major elements are not able to explain the large range in $\mathrm{K}_{2} \mathrm{O}, \mathrm{TiO}_{2}$, and LIL trace element abundances. Similar genetic problems are encountered at other ocean ridge spreading centers. Apparently, the parental magmas for Leg 34 basalts differed significantly in LIL element abundances; such differences probably reflect different degrees of melting of the source material and/or source heterogeneity.
\end{abstract}

\section{INTRODUCTION}

Petrographic and geochemical data are presented for 20 basalt samples obtained from cores at DSDP Leg 34 Sites 319,320 , and 321 on the Nazca plate (Figure 1). Details of drilling sites and hole summaries are given elsewhere in this volume (Chapters 3-5). Sample locations and the numbering system used in this report are shown in Figure 2 with reference to lithologic units defined by the shipboard scientists; complete DSDP sample numbers, which are not used in this report, are given in Table 1.

Laboratory procedures described by Frey et al. (1974) were used. Analytical precision and data for reference standards are given in Table 2.

\section{PETROGRAPHY}

The samples can be divided into five petrographic and geochemical groups (Figure 2). Samples not petrographically studied were placed in specific groups in Figure 2 on compositional characteristics. Compared to most recent ocean ridge basalts, the Leg 34 basalts are remarkable for the paucity or lack of olivine and the abundance of clinopyroxene microphenocrysts and magnetite. Modal compositions of some of the holocrystalline samples are given in Table 3.

Group I (Represented by Samples 1, 2, 3, From the Upper Parts of Holes 319 and 319A)

Plagioclase microphenocrysts, in "bow-tie" intergrowths with clinopyroxene (Figure 3a), lie in a variolitic, pyroxene-rich groundmass with interstitial magnetite (Figure $3 b$ ). Traces of quench olivine appear only in Sample 1. Apparently these samples lie on or close to a plagioclase-pyroxene cotectic, but do not intersect the magnetite field until a significant amount of crystallization has taken place.

Group II (Represented by Samples 5, 6, 8, 9, 10, 11, 12 From the Lower Part of Hole 319A)

These are microdolerites of variable texture and grain size, presumably due to different positions in the cooling units (Figure 2). Plagioclase and clinopyroxene pre- 


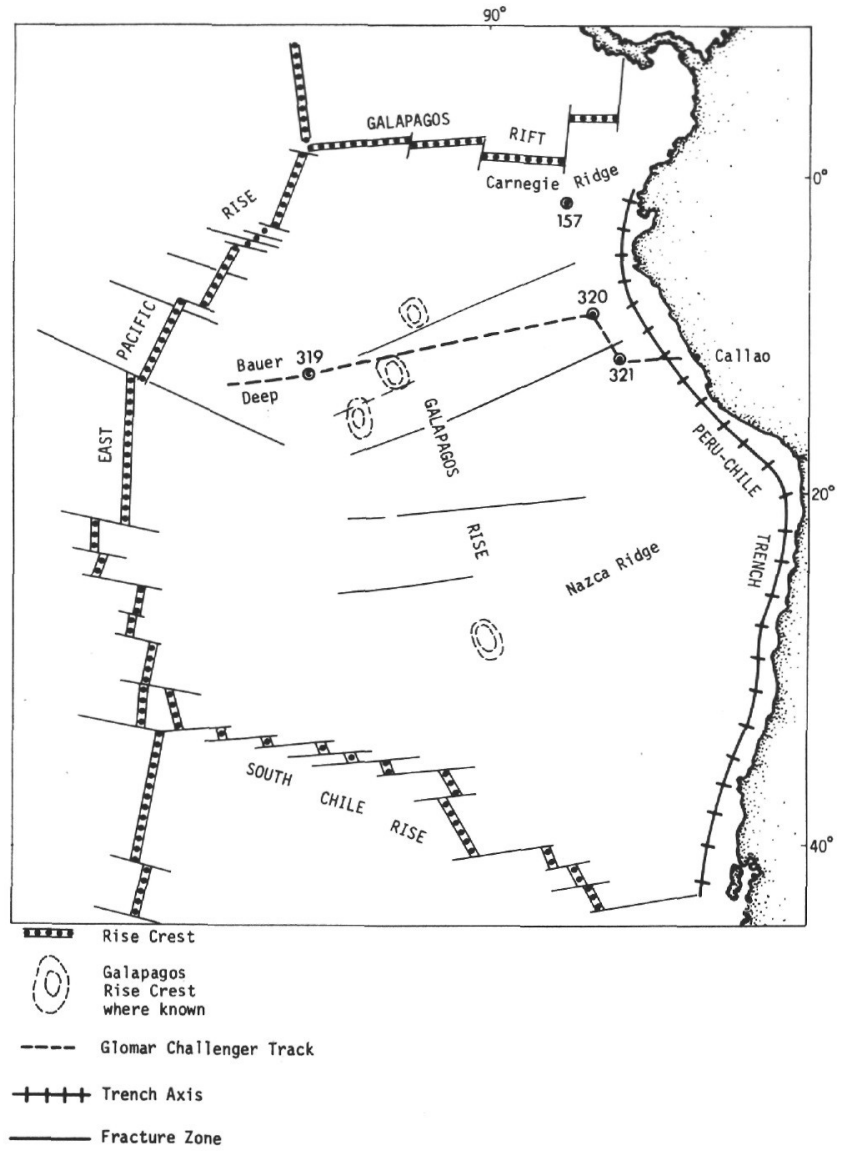

Figure 1. Nazca plate showing major tectonic features and DSDP sites.

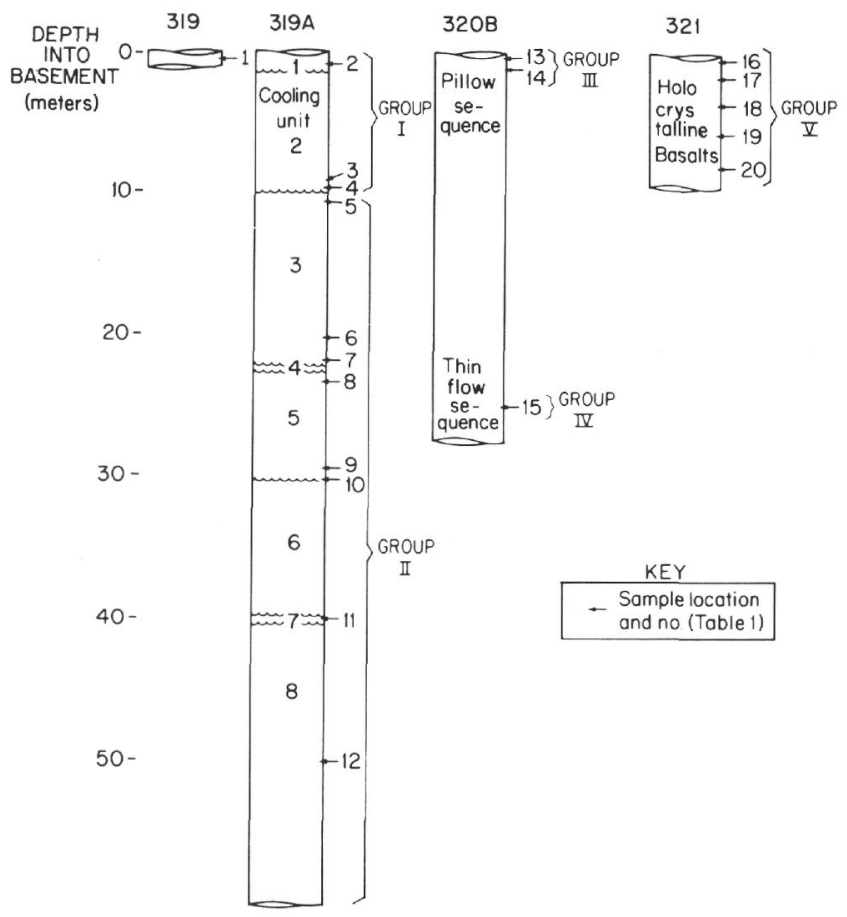

Figure 2. Leg 34 basalt units with sample distribution and numbering as used in this paper. dominate (Table 3). Magnetite is abundant, particularly in iron-rich groundmass segregations. Earlyformed plagioclase crystals are relatively large (to 1 $\mathrm{mm}$ ), subequant, and zoned outwards to more sodic compositions. Early clinopyroxenes form rounded blades (to $1 \mathrm{~mm}$ ) with outwardly increasing $\mathrm{Fe} / \mathrm{Mg}$ ratios. The groundmass is typically a subophitic assemblage of clinopyroxene enclosing plagioclase. Examples of "bow-tie" intergrowths (Figure 3a) and cryptocrystalline sheaves of pyroxene, plagioclase, and magnetite (Figure $3 \mathrm{~b}$ ) appear in the groundmass. Sector zoning can be found in some plagioclase cores, and occasionally in the pyroxenes. Some of the plagioclase, along with most of the pyroxene, consists of bent, optically strained crystals with wavy or patchy extinction. These features are suggestive of rapid growth induced by quenching, or perhaps influenced by mineralizing fluids in the magmas. Olivine phenocrysts have been identified in only one rock (Sample 9) in this group of microdolerites although some micaceous patches have rounded outlines suggestive of olivine pseudomorphs. In one other rock (Sample 8 ) olivine ( $\mathrm{Fo}_{74}$ ) occurs as relicts within patches of birefringent secondary material; olivine constitutes less than $5 \%$.

There are three kinds of cryptocrystalline patchy areas in these rocks. The first (Figure 3c) consists of fanlike wispy crystals of pyroxene-plagioclase intergrowths with magnetite, and these may form either irregular interstitial patches or distinct fillings in rare, circular vesicles. In both cases, coarser pyroxene, plagioclase, and magnetite crystals bordering the patch may be optically continuous with skeletal extensions into the patch. Magnetite is especially concentrated in these patches, which may represent segregations of late-stage ironenriched residual silicate magma. The second type of cryptocrystalline patch consists of finely granular, birefringent material (smectite) which may fill vesicles or form irregular, groundmass patches. The third variety is a highly birefringent, micaceous material forming bastite-like patches. Some of these have rounded outlines suggestive of olivine pseudomorphs, but many show textural relationships that suggest they replace pyroxenes.

Group III (Represented by Sample 13 From the Upper Part of Hole 320B)

Acicular plagioclase microlites show typical "beltbuckle" form in cross-section and traces of sector zoning. Olivine microphenocrysts (Fo85) are rare and may be intergrown with plagioclase. The groundmass is cryptocrystalline, appearing to be mainly pyroxene-plagioclase intergrowths. Alteration is $10 \%$ to $15 \%$, preferentially replacing the groundmass.

\section{Group IV (Represented by Sample 15 From the Lower Part of Hole 320B)}

The shipboard scientists have distinguished this unit from the rest of 320B by its massiveness, homogeneity, and the presence of conchoidal fractures. Sample 15, a glassy margin from this unit, contains microlites of plagioclase and pyroxene and has a distinctive chemical composition. 
TABLE 1

Sample Numbers and Lithology

\begin{tabular}{|c|c|c|}
\hline $\begin{array}{l}\text { Sample } \\
\text { No. }\end{array}$ & $\begin{array}{c}\text { Sample } \\
\text { (Interval in } \mathrm{cm} \text { ) }\end{array}$ & Lithology \\
\hline 1 & $319-13-1,58-64$ & Chilled margin of flow - glass analyzed by microprobe \\
\hline 2 & $319 \mathrm{~A}-1-1,14-17$ & Crystalline, flow interior \\
\hline 3 & $319 A-2-1,26-30$ & Crystalline, flow interior near base \\
\hline 4 & $319-A-2,1-30$ & Glass, base of flow - glass analyzed by microprobe \\
\hline 5 & $319 A-2-2,4-7$ & Crystalline, flow interior \\
\hline 6 & $319 A-3-2,108-112$ & Crystalline, flow interior \\
\hline 7 & $319 A-3-4,50-53$ & Crystalline, flow interior \\
\hline 8 & $319 A-3-6,138-141$ & Crystalline, flow interior \\
\hline 9 & $319 A-4-1,133-136$ & Crystalline, flow interior \\
\hline 10 & $319 A-5-1,87-90$ & Crystalline, flow interior \\
\hline 11 & $319 A-6-1,77-78$ & Crystalline, flow interior \\
\hline 12 & $319 A-7-1,40-43$ & Crystalline, flow interior \\
\hline 13 & $320 \mathrm{~B}-3-1,76-79$ & Crystalline, flow interior \\
\hline 14 & 320B-3-1, 101-105 & Chilled margin of flow - glass analyzed by microprobe \\
\hline 15 & $320 \mathrm{~B}-5-1,127-131$ & Chilled margin of flow - glass analyzed by microprobe \\
\hline 16 & $321-13-4,94-97$ & Crystalline, flow interior \\
\hline 17 & $321-14-1,39-42$ & Crystalline, flow interior \\
\hline 18 & $321-14-2,12-15$ & Crystalline, flow interior \\
\hline 19 & $321-14-3,34-37$ & Crystalline, flow interior \\
\hline 20 & $321-14-4,20-23$ & Crystalline, flow interior \\
\hline
\end{tabular}

TABLE 2

Analyses of Standard Rocks

\begin{tabular}{|c|c|c|c|c|c|c|c|c|c|c|}
\hline & \multicolumn{2}{|c|}{ Major Elements } & \multicolumn{8}{|c|}{ Trace Elements } \\
\hline & A & B & & C & D & $\mathrm{E}$ & $\mathrm{F}$ & & G & $\mathrm{H}$ \\
\hline $\mathrm{SiO}_{2}$ & 50.81 & $51.2 \pm 0.2$ & B & $10 \pm 2$ & 15 & $<5$ & 5 & $\mathrm{Sc}$ & $36.8 \pm 0.9$ & 33 \\
\hline $\mathrm{Al}_{2} \mathrm{O}_{3}$ & 14.06 & $13.6 \pm 0.2$ & $\mathrm{Li}$ & $11 \pm 1$ & 14 & $12 \pm 2$ & 13 & $\mathrm{La}$ & $24 \pm 1$ & 26 \\
\hline $\mathrm{FeO}^{*}$ & 11.84 & $11.6 \pm 0.1$ & $\mathrm{~V}$ & $240 \pm 5$ & 264 & $450 \pm 20$ & 400 & $\mathrm{Ce}$ & $51.3 \pm 3.2$ & 53.9 \\
\hline $\mathrm{MgO}$ & 6.71 & $7.11 \pm 0.16$ & $\mathrm{Cr}$ & $110 \pm 3$ & 114 & $12 \pm 2$ & 18 & $\mathrm{Nd}$ & $28.5 \pm 2.0$ & 29 \\
\hline $\mathrm{CaO}$ & 11.12 & $10.9 \pm 0.1$ & Co & $47 \pm 2$ & 47 & $39 \pm 1$ & 38 & & & \\
\hline $\mathrm{Na}_{2} \mathrm{O}$ & $2.62^{\mathrm{a}}$ & $2.83 \pm 0.1$ & $\mathrm{Ni}$ & $80 \pm 5$ & 76 & $15 \pm 2$ & 16 & $\mathrm{Sm}$ & $6.60 \pm 0.25$ & 6.6 \\
\hline $\mathrm{K}_{2} \mathrm{O}$ & 0.19 & $0.20 \pm 0.01$ & $\mathrm{Cu}$ & $120 \pm 6$ & 110 & $16 \pm 3$ & 18 & $\mathrm{Eu}$ & $1.87 \pm 0.13$ & 1.94 \\
\hline $\mathrm{TiO}_{2}$ & 1.85 & $1.85 \pm 0.03$ & $\mathrm{Ga}$ & $17 \pm 1$ & 16 & $21 \pm 2$ & 20 & $\mathrm{~Tb}$ & $1.1 \pm 0.1$ & 1.0 \\
\hline $\mathrm{MnO}$ & 0.22 & $0.19 \pm 0.03$ & $\mathrm{Sr}$ & $170 \pm 20$ & 190 & $280 \pm 33$ & 330 & Ho & $1.46 \pm 0.11$ & 1.2 \\
\hline \multirow[t]{4}{*}{ Total } & 99.49 & 99.48 & $\mathrm{Ba}$ & $130 \pm 7$ & 160 & $600 \pm 80$ & 675 & $\mathrm{Yb}$ & $3.43 \pm 0.31$ & 3.36 \\
\hline & & & $\mathrm{Y}$ & $24 \pm 6$ & 25 & $45 \pm 4$ & 37 & $\mathrm{Lu}$ & $0.56 \pm 0.01$ & 0.55 \\
\hline & & & $\mathrm{Zr}$ & $100 \pm 10$ & 105 & $200 \pm 15$ & 190 & Hf & $5.5 \pm 0.2$ & 4.7 \\
\hline & & & & & & & & $\mathrm{Ta}$ & $0.84 \pm 0.09$ & 0.91 \\
\hline
\end{tabular}

*Total iron as $\mathrm{FeO}$

Note: A-Juan de Fuca Ridge (JFR) glass, wet chemical analy sis, E. Jarosewich, Smithsonian Institution; B-Mean and standard deviation of electron microprobe (MIT) analyses of three different chips of JFR glass; C, E-Mean and standard deviation of triplicate emission spectrometric analyses of ref. rock W-1 + BCR-1 obtained during analyses of Leg 34 samples; D, F-Recommended values for W-1 + BCR-1 (Flanagan, 1972); G-Mean and standard deviation for triplicate analyses of BCR-1 by instrumental neutron activation analysis; $\mathrm{H}-\mathrm{Recommended}$ values for BCR-1 (Flanagan, 1972).

aNew value given by E. Jarosewich (personal communication). 
TABLE 3

Modal Proportions in Volume Percent ${ }^{\text {a }}$

\begin{tabular}{ccccccc}
\hline Group & Sample No.b & Plagioclase & Pyroxene & Opaques & Vesicles & Otherc $^{c}$ \\
\hline II & 5 & 42.5 & 32.8 & 7.1 & - & 17.6 \\
II & 8 & 45.2 & 30.7 & 6.3 & - & 17.8 \\
V & 17 & 36.5 & 40.0 & 10.3 & 0.3 & 12.8 \\
\hline
\end{tabular}

aCount area: $150 \mathrm{~mm}^{2} ; 1500$ points.

bSee Table 1 and Figure 2.

cIncludes cryptocrystalline groundmass and altered patches.

\section{Group V (Represented by Samples 16, 17, 18, 19, 20 From} Site 321)

This group is composed of microdolerites consisting of networks of plagioclase laths (to $0.2 \mathrm{~mm}$ ) with abundant intergranular pyroxene and magnetite. Pyroxene exceeds plagioclase in abundance (Table 3). Magnetite is especially abundant, both as inclusions in the outer zones of plagioclase and clinopyroxene phenocrysts, and, in the groundmass, occupying interstices of plagioclase-pyroxene intergrowths. Sulphide is conspicuous in some veins and vesicles, appearing in most cases to have invaded the rock along fractures. All samples contain vesicles, many of which contain traces of cryptocrystalline silicate, carbonate, smectite, or chlorite. In Sample 19 a sulphide globule was enclosed in a silicate matrix within a vesicle. Patches of brownish alteration constitute up to $15 \%$ of the rocks.

In summary, textures in most of the basalts and dolerites studied indicate early precipitation of plagioclase, accompanied or soon joined by clinopyroxene (not olivine) and later magnetite. In many rocks, particularly of Group V, magnetite is notably abundant, which suggests that the rocks crystallized from iron-enriched, fractionated magmas. Quench features abound, as in most igneous rocks of the sea floor.

\section{MINERALOGY}

Silicates in the doleritic rocks (Group II) from the lower part of Hole 319A have been analyzed by electron microprobe.

Plagioclase (Table 4A) ranges from $A_{75}$ to $A_{n_{55}}$, and marginal zones of some grains appear (optically) to be more sodic than $\mathrm{An}_{50}$. As with sea-floor basalt plagioclases previously analyzed (Bryan, 1975), there is a significant amount of $\mathrm{Fe}$ and $\mathrm{Mg}$ in the plagioclase. The concentration of $\mathrm{Fe}$ and $\mathrm{Mg}$ increases with $\mathrm{Na}$ content as does the $\mathrm{Fe} / \mathrm{Mg}$ ratio. The increasing $\mathrm{Fe} / \mathrm{Mg}$ probably reflects $\mathrm{Fe}$ enrichment in the liquid due to pyroxene crystallization.

Clinopyroxenes (Table 4B) are aluminous diopsidic augites typical of more fractionated sea-floor basalts (Frey et al., 1975). The wavy, patchy optical extinction is not always accompanied by compositional variation. Thus, the optical discontinuities are at least partly due to mechanical distortion of the crystal. Where distinct sector zoning is visible, there are significant variations in $\mathrm{SiO}_{2}, \mathrm{TiO}_{2}$, and $\mathrm{Al}_{2} \mathrm{O}_{3}$ abundances, suggesting that most of the chemical differences between sectors is due to coupled substitutions of these elements (Table 4B, column 4).
Olivine (Table 4C) was observed as phenocrysts only in Sample 9 of Hole 319A. The three crystals analyzed are very similar ( $\mathrm{FO}_{85}$ to $\mathrm{Fo}_{87}$ ); this is within the composition range of olivines from other sea-floor basalts.

\section{CHEMISTRY}

Electron microprobe major element analyses of fresh natural glasses are given in Table 5. To supplement these data we have also analyzed by electron microprobe several fluxed glasses prepared from the crystalline basalts (Reed, 1970); these results are also given in Table 5 . One of the samples (15b) was analyzed as a fluxed glass prepared from large samples of the glass analyzed directly by microprobe (15a); the results are in good agreement (less than 5\% deviation except for $\mathrm{Ca}$ which showed $10 \%$ difference), giving confidence in the fluxed glass analytical technique. Trace element analyses by direct-reading emission spectrometry and instrumental neutron activation are given in Table 6. The elements in this table are divided into three sets: Set I-elements and oxides known to be sensitive indicators of alteration and reaction with seawater (Hart, 1969; Thompson, 1973); Set II-first series transition elements plus $\mathrm{Ga}$; and Set III (A and B)-LIL elements.

As a whole the Leg 34 basalts are depleted in the LIL elements such as $\mathrm{K}, \mathrm{Ti}, \mathrm{Ba}, \mathrm{Sr}, \mathrm{Zr}$, and REE when compared to island and continental tholeiitic basalts; this is a feature typical of many ocean ridge basalts (e.g., Engel et al., 1965; Melson et al., 1968; Frey et al., 1968; Hart, 1969; Kay et al., 1970; Frey et al., 1975). There are, however, distinctive chemical characteristics of each Leg 34 group (Figure 2). These important differences may reflect magmatic processes.

\section{Group I}

The two glass chips (Samples 1 and 4) are very similar in major element composition to each other and to the crystalline Sample 3 (Table 5). All four samples in this group have very similar trace element compositions (Table 6) which is consistent with the observed similarity in petrography. Of all the Leg 34 basalts, this group has the lowest $\mathrm{Fe} / \mathrm{Mg}$ and concentrations of $\mathrm{K}, \mathrm{Ti}, \mathrm{V}, \mathrm{Ba}$, $\mathrm{Y}, \mathrm{Zr}, \mathrm{Hf}$, and REE; $\mathrm{Ca}, \mathrm{Mg}, \mathrm{Cr}, \mathrm{Ni}, \mathrm{Cu}$, and $\mathrm{Sc}$ are relatively high in concentration. Relatively low concentrations of $\mathrm{H}_{2} \mathrm{O}, \mathrm{CO}_{2}, \mathrm{~B}$, and $\mathrm{Li}$ (compared to other DSDP basalts of similar age) indicate that these samples are not badly weathered in spite of the apparent basement age of $15 \times 10^{6} \mathrm{yr}$. The overall petrographic and chemical uniformity suggests that this group represents a single magma unit. 

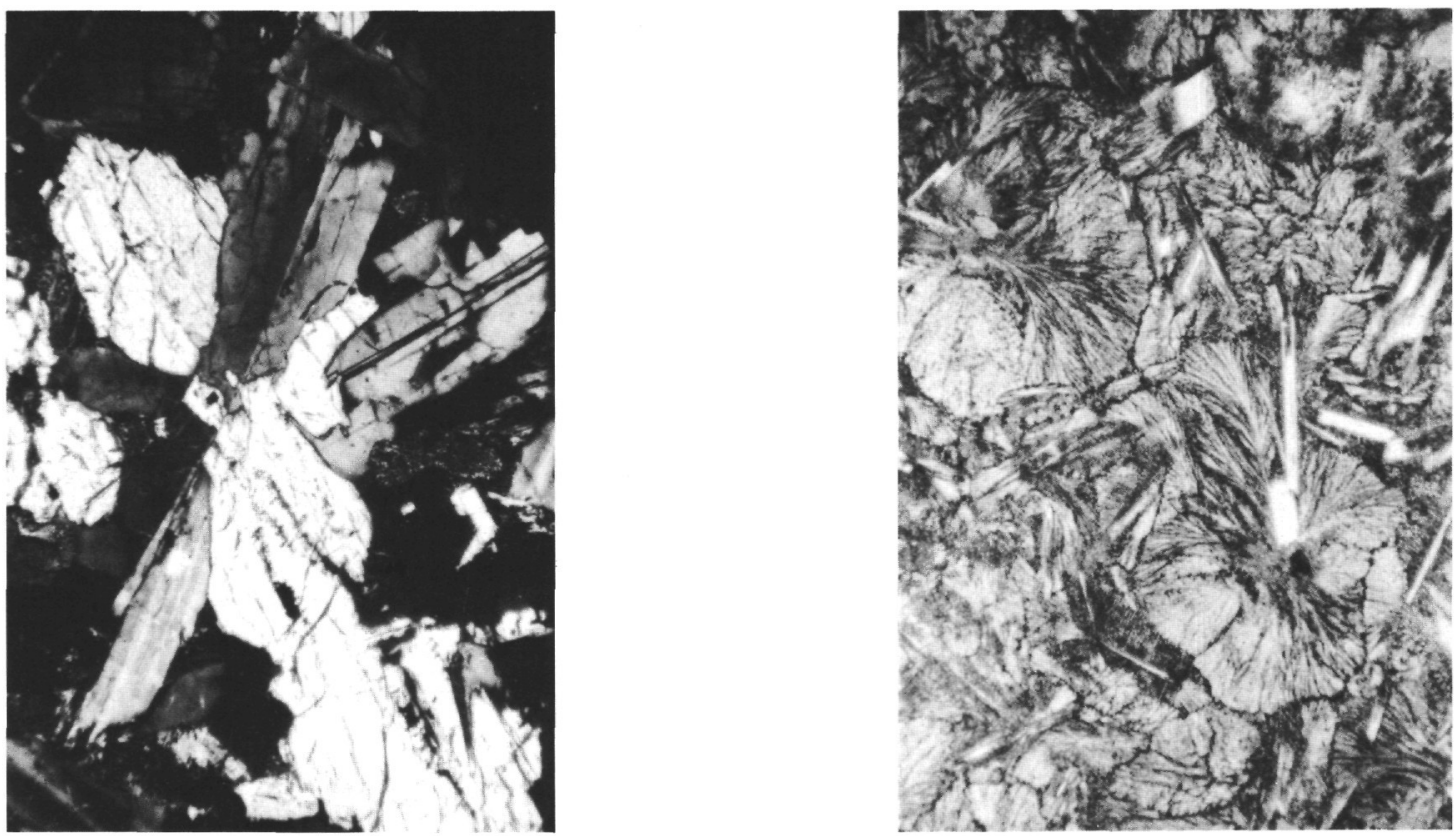

a.

b.

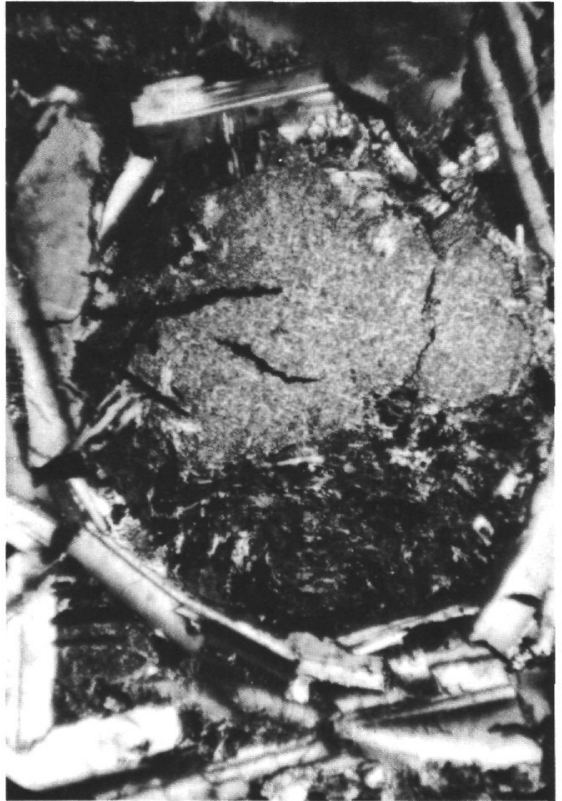

c.

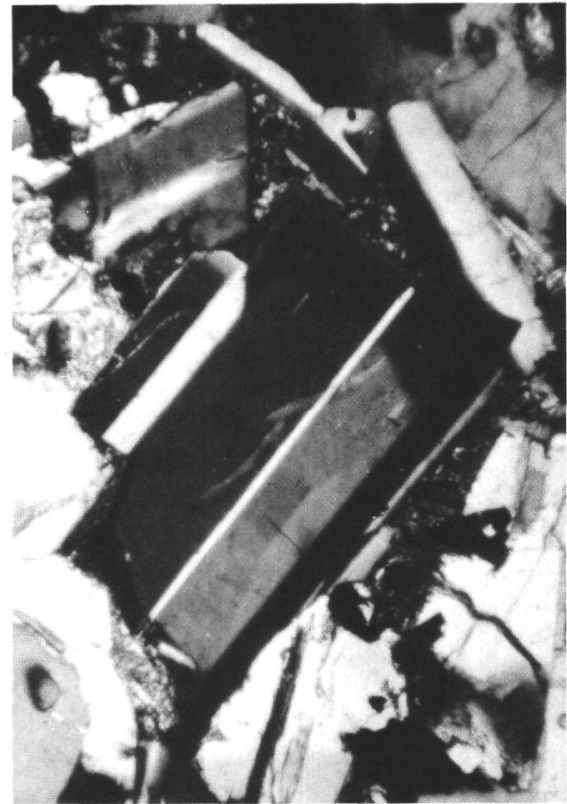

d.

Figure 3. Textures and growth forms in Leg 34 basalts. (a) Plagioclase (dark) and augite (light) in "bow tie" intergrowth; Sample 319A-2-2, 4-7 cm (No. 5); polarized light. (b) Variolithic texture adjacent to glass margin; Sample 319-13-1, 58-64 cm (No. 1); plain light. (c) Circular vug with enclosed cryptocrystalline silicate filling (dark) and granular, birefringent smecite (light); Sample 319A-2-2, 4-7 cm (No. 5); polarized light. (d) Relict sector-zone core in plagioclase; Sample 319A-3-6, 138-141 cm (No. 8); polarized light. Dimensions of photographs are $0.8 \times 1.0 \mathrm{~mm}$. 
TABLE 4A

Electron Microprobe Analyses of Plagioclase

\begin{tabular}{|c|c|c|c|c|c|}
\hline & \multicolumn{3}{|c|}{ Sample No. $7^{a}$} & \multicolumn{2}{|c|}{ Sample No. 9a } \\
\hline & $\mathrm{A}$ & B & $\mathrm{C}$ & $\mathrm{D}$ & $\mathrm{E}$ \\
\hline $\mathrm{SiO}_{2}$ & 50.6 & 55.3 & 50.5 & 52.8 & 53.4 \\
\hline $\mathrm{TiO}_{2}$ & 0.02 & 0.10 & 0.04 & 0.07 & 0.07 \\
\hline $\mathrm{Al}_{2} \mathrm{O}_{3}$ & 31.1 & 27.8 & 31.0 & 28.8 & 27.9 \\
\hline $\mathrm{FeO}$ & 0.48 & 0.87 & 0.51 & 0.64 & 0.90 \\
\hline $\mathrm{MnO}$ & 0.02 & 0.00 & 0.00 & 0.00 & 0.00 \\
\hline $\mathrm{MgO}$ & 0.25 & 0.20 & 0.27 & 0.30 & 0.41 \\
\hline $\mathrm{CaO}$ & 15.5 & 11.5 & 15.2 & 12.3 & 11.9 \\
\hline $\mathrm{Na}_{2} \mathrm{O}$ & 2.91 & 5.30 & 3.11 & 4.36 & 4.46 \\
\hline $\mathrm{K}_{2} \mathrm{O}$ & 0.01 & 0.04 & 0.01 & 0.02 & 0.03 \\
\hline $\mathrm{Cr}_{2} \mathrm{O}_{3}$ & 0.04 & 0.00 & 0.00 & 0.00 & 0.00 \\
\hline Total & 100.93 & 101.11 & 100.64 & 99.29 & 99.07 \\
\hline $\mathrm{O} \equiv$ & 8.000 & 8.000 & 8.000 & 8.000 & 8.000 \\
\hline $\mathrm{Si}$ & 2.293 & 2.479 & 2.296 & 2.412 & 2.445 \\
\hline $\mathrm{Ti}$ & 0.000 & 0.002 & 0.000 & 0.001 & 0.002 \\
\hline Al & 1.661 & 1.470 & 1.660 & 1.553 & 1.506 \\
\hline $\mathrm{Fe}$ & 0.017 & 0.031 & 0.019 & 0.024 & 0.034 \\
\hline $\mathrm{Mn}$ & 0.000 & 0.000 & 0.000 & 0.000 & 0.000 \\
\hline $\mathrm{Mg}$ & 0.017 & 0.012 & 0.017 & 0.020 & 0.028 \\
\hline $\mathrm{Ca}$ & 0.750 & 0.552 & 0.737 & 0.600 & 0.584 \\
\hline $\mathrm{Na}$ & 0.255 & 0.460 & 0.273 & 0.386 & 0.396 \\
\hline K & 0.000 & 0.001 & 0.000 & 0.000 & 0.002 \\
\hline $\mathrm{Cr}$ & 0.001 & $\underline{0.000}$ & $\underline{0.000}$ & $\underline{0.000}$ & 0.000 \\
\hline Total & 4.994 & 5.008 & 5.002 & 4.996 & 4.997 \\
\hline
\end{tabular}

Note: A-phenocryst; B-microphenocryst; C-plagioclase in ophitic growth with pyroxene; D-microphenocryst; E-phenocryst.

asee Table 1 and Figure 2.

\section{Group II}

These basalts from the lower part of Hole 319A (Figure 2) represent a number of different flow units with slightly different grain sizes, but they have similar chemical compositions. Compared to the overlying Group I basalts, this group is characterized by higher $\mathrm{Fe} / \mathrm{Mg}$ and concentrations of $\mathrm{Ti}, \mathrm{Al}, \mathrm{Na}, \mathrm{V}, \mathrm{Ga}, \mathrm{Sr}, \mathrm{Y}$, $\mathrm{Zr}, \mathrm{Hf}$, and REE. For example, $\mathrm{La}$ and $\mathrm{Ce}$ are enriched by nearly a factor of 2 and the heavy REE are increased by a factor of $1.5 . \mathrm{Mg}, \mathrm{Cr}, \mathrm{Ni}, \mathrm{Cu}$, and $\mathrm{Sc}$ are lower in concentration in the Group II basalts, with the exception of Sample 11 which has an anomalously high $\mathrm{Ni}$ concentration. Basalts of Group II are relatively fresh; those with higher $\mathrm{H}_{2} \mathrm{O}$ contents have higher $\mathrm{Li}$ concentrations. B is enriched in only Sample 6 (Table 6).

\section{Group III}

This group from the upper part of Hole 320B is represented by two samples of very similar chemical composition. Compared to Group I basalts of Hole 319, they
TABLE 4B

Electron Microprobe Analy ses of Augite, Sample No. 7

\begin{tabular}{lcccl}
\hline & $\mathrm{A}$ & $\mathrm{B}$ & $\mathrm{C}$ & \multicolumn{1}{c}{$\mathrm{D}^{\mathrm{a}}$} \\
\hline $\mathrm{SiO}_{2}$ & 50.8 & 51.4 & 51.4 & $51.9(50.8-52.5)$ \\
$\mathrm{TiO}_{2}$ & 1.23 & 1.33 & 1.18 & $0.88(0.60-1.25)$ \\
$\mathrm{Al}_{2} \mathrm{O}_{3}$ & 3.23 & 3.78 & 3.35 & $3.19(2.49-4.05)$ \\
$\mathrm{FeO}$ & 8.91 & 7.62 & 7.98 & 7.54 \\
$\mathrm{MnO}$ & 0.22 & 0.17 & 0.20 & 0.19 \\
$\mathrm{MgO}$ & 15.4 & 15.7 & 15.7 & 17.0 \\
$\mathrm{CaO}$ & 19.0 & 20.2 & 20.0 & 18.6 \\
$\mathrm{Na} 2 \mathrm{O}$ & 0.32 & 0.30 & 0.30 & 0.27 \\
$\mathrm{~K} 2 \mathrm{O}$ & 0.00 & 0.00 & 0.00 & 0.00 \\
$\mathrm{Total}$ & 99.43 & 100.76 & 100.41 & 99.84 \\
$\mathrm{O} \equiv$ & 6.000 & 6.000 & 6.000 & 6.000 \\
$\mathrm{Si}$ & 1.894 & 1.883 & 1.894 & 1.910 \\
$\mathrm{Ti}$ & 0.034 & 0.036 & 0.032 & 0.023 \\
$\mathrm{Al}$ & 0.141 & 0.162 & 0.145 & 0.138 \\
$\mathrm{Fe}$ & 0.276 & 0.233 & 0.245 & 0.231 \\
$\mathrm{Mn}$ & 0.006 & 0.004 & 0.005 & 0.005 \\
$\mathrm{Mg}$ & 0.854 & 0.857 & 0.861 & 0.931 \\
$\mathrm{Ca}$ & 0.760 & 0.794 & 0.788 & 0.731 \\
$\mathrm{Na}$ & 0.023 & 0.020 & 0.021 & 0.018 \\
$\mathrm{~K}$ & 0.000 & 0.000 & 0.000 & 0.000 \\
$\mathrm{Cr}$ & 0.008 & 0.007 & 0.008 & 0.007 \\
$\mathrm{Total}$ & 3.997 & 3.997 & 4.000 & 3.996 \\
\hline $\mathrm{a}$ & & & &
\end{tabular}

${ }^{\mathrm{a}}$ Column D is a sector zoned crystal, ranges in composition shown in parentheses.

have similar $\mathrm{Fe}$ and $\mathrm{Mg}$ abundances and $\mathrm{Fe} / \mathrm{Mg}$, but slightly higher concentrations of $\mathrm{K}, \mathrm{Ti}, \mathrm{V}, \mathrm{Y}, \mathrm{Zr}$, and $\mathrm{REE}$. Interestingly, the $\mathrm{Cr}$ and $\mathrm{Ni}$ contents are slightly higher in Group III than in Group I basalts. Although older than the Group I basalts $\left(28 \times 10^{6} \mathrm{yr}\right)$, they are still relatively unaltered; however, one sample (13, Table 6) has high water and Li contents.

\section{Group IV}

This group is represented by only one glass sample, which is very different in composition from the overlying Group III basalts of Hole 320B. For example, it has much higher $\mathrm{Fe} / \mathrm{Mg}$ and higher $\mathrm{K}, \mathrm{Ti}$, and $\mathrm{Fe}$ concentrations and lower $\mathrm{Al}, \mathrm{Ca}$, and $\mathrm{Mg}$ contents. Similarly in trace elements Group IV basalt has much higher concentrations of $\mathrm{V}, \mathrm{Y}, \mathrm{Zr}$, and $\mathrm{REE}$ and lower concentrations of $\mathrm{Cr}, \mathrm{Ni}$, and $\mathrm{Cu}$.

\section{Group V}

Basalts from Site 321 are very similar in composition and petrography. Compared to Groups I, II, and III from Holes 319 and 320, they have higher $\mathrm{Fe} / \mathrm{Mg}$ and higher concentrations of $\mathrm{Ti}$ and $\mathrm{Fe}$ and lower concentrations of $\mathrm{Al}, \mathrm{Ca}$, and $\mathrm{Mg}$. In trace elements this group is characterized by high concentrations of $\mathrm{V}, \mathrm{Ba}, \mathrm{Y}, \mathrm{Zr}$, $\mathrm{Hf}$, and $\mathrm{REE}$ and low concentrations of $\mathrm{Cr}, \mathrm{Ni}$, and $\mathrm{Cu}$. 
TABLE 4C

Electron Microprobe Analyses of Olivine, Sample No. 9

\begin{tabular}{lccc}
\hline $\mathrm{SiO}_{2}$ & 39.4 & 39.6 & 39.4 \\
$\mathrm{TiO}_{2}$ & 0.01 & 0.02 & 0.01 \\
$\mathrm{Al}_{2} \mathrm{O}_{3}$ & 0.07 & 0.05 & 0.04 \\
$\mathrm{FeO}$ & 13.5 & 13.6 & 13.5 \\
$\mathrm{MnO}$ & 0.23 & 0.26 & 0.25 \\
$\mathrm{MgO}$ & 46.6 & 46.5 & 45.7 \\
$\mathrm{CaO}$ & 0.30 & 0.30 & 0.31 \\
$\mathrm{Na} 2 \mathrm{O}$ & 0.02 & 0.00 & 0.01 \\
$\mathrm{~K}_{2} \mathrm{O}$ & 0.00 & 0.01 & 0.00 \\
$\mathrm{Cr} 2 \mathrm{O}_{3}$ & 0.06 & 0.08 & 0.09 \\
\cline { 2 - 4 } & 100.19 & 100.42 & 99.31 \\
$\mathrm{O} \equiv$ & 4.000 & 4.000 & 4.000 \\
$\mathrm{Si}$ & 0.984 & 0.991 & 0.991 \\
$\mathrm{Ti}$ & 0.000 & 0.000 & 0.000 \\
$\mathrm{Al}$ & 0.001 & 0.000 & 0.000 \\
$\mathrm{Fe}$ & 0.281 & 0.282 & 0.283 \\
$\mathrm{Mn}$ & 0.004 & 0.005 & 0.005 \\
$\mathrm{Mg}$ & 1.732 & 1.727 & 1.712 \\
$\mathrm{Ca}$ & 0.007 & 0.007 & 0.008 \\
$\mathrm{Cr}$ & $\underline{0.001}$ & $\underline{0.001}$ & $\underline{0.001}$ \\
& 3.012 & 3.007 & 3.001 \\
\hline & & &
\end{tabular}

Although apparently the oldest Leg 34 basalts $\left(40 \times 10^{6}\right.$ $\mathrm{yr})$, they are not badly weathered (0.9-1.7 wt \% $\left.\mathrm{H}_{2} \mathrm{O}\right)$; only one sample (No. 19) is markedly enriched in B.

\section{DISCUSSION}

The Leg 34 basalts resemble many other ocean ridge basalts in their major and minor element characteristics and especially in their low concentration of LIL elements. In particular, they resemble other basalts from the East Pacific Rise and Nazca plate (Table 7 and Figure 4). It is especially interesting that, in spite of the considerable variations in certain major elements and trace elements, this LIL-depleted characteristic is retained throughout the whole series of Leg 34 basalts investigated. The variation in composition of the Leg 34 basalt groups is quite systematic and suggests operation of a common process on source rocks of similar compositions. The Group I basalts of the upper part of Hole 319 appear to be the least fractionated or most LIL-element depleted. However, compared with the most-primitive or less-fractionated oceanic basalts reported in the literature (see Table 8), it is apparent that the Hole 319 Group I basalts are already well fractionated in terms of $\mathrm{FeO} / \mathrm{MgO}, \mathrm{TiO}_{2}$, and concentrations of LIL elements; these are parameters which we regard as the most definitive variables in unaltered oceanic basalts. These chemical features are consistent with petrographic observations such as the abundance of clinopyroxene and, especially, the scarcity of olivine. Rather than lying on or close to the olivine-plagioclase cotectic, as do many

TABLE 5

Major Element Composition of DSDP Leg 34 Basalts (wt \%)

\begin{tabular}{|c|c|c|c|c|c|c|c|c|c|}
\hline & \multicolumn{3}{|c|}{ Group I } & \multicolumn{2}{|c|}{ Group II } & \multirow{2}{*}{$\frac{\text { Group III }}{14}$} & \multicolumn{2}{|c|}{ Group IV } & \multirow{2}{*}{$\frac{\text { Group V }}{20^{b}}$} \\
\hline & 1 & $3^{b}$ & 4 & $5^{b}$ & $11^{b}$ & & $15 \mathrm{a}$ & $15 \mathrm{~b}^{\mathrm{b}}$ & \\
\hline $\mathrm{SiO}_{2}$ & 52.13 & 51.2 & 52.00 & 51.2 & 50.1 & 51.37 & 52.55 & 52.6 & 51.6 \\
\hline $\mathrm{Al}_{2} \mathrm{O}_{3}$ & 14.49 & 15.2 & 14.54 & 15.3 & 15.5 & 15.39 & 13.65 & 14.1 & 13.8 \\
\hline $\mathrm{FeO}^{\mathrm{c}}$ & 9.62 & 9.7 & 9.53 & 11.5 & 10.7 & 9.48 & 12.04 & 12.6 & 13.1 \\
\hline $\mathrm{MgO}$ & 8.07 & 8.1 & 7.99 & 6.9 & 6.3 & 7.89 & 6.58 & 6.4 & 6.6 \\
\hline $\mathrm{CaO}$ & 11.42 & 12.7 & 11.34 & 11.3 & 12.1 & 10.60 & 9.42 & 10.5 & 10.3 \\
\hline $\mathrm{Na}_{2} \mathrm{O}$ & 2.49 & 2.4 & 2.48 & 2.8 & 2.8 & 2.80 & 2.74 & 2.7 & 2.5 \\
\hline $\mathrm{K}_{2} \mathrm{O}$ & 0.04 & - & 0.04 & - & - & 0.07 & 0.09 & - & - \\
\hline $\mathrm{TiO}_{2}$ & 1.15 & 1.2 & 1.17 & 2.2 & 1.9 & 1.46 & 2.10 & 2.0 & 2.4 \\
\hline $\mathrm{MnO}$ & 0.16 & 0.1 & 0.16 & 0.2 & 0.2 & 0.16 & 0.18 & 0.2 & 0.2 \\
\hline Total & 99.62 & 100.8 & 99.26 & 101.6 & 99.9 & 99.28 & 99.41 & 101.4 & 100.7 \\
\hline $\mathrm{FeO} / \mathrm{MgO}$ & 1.19 & 1.20 & 1.19 & 1.67 & 1.70 & 1.20 & 1.83 & 1.97 & 1.98 \\
\hline
\end{tabular}

Note: $1-319-13-1,58-64-$ natural glass; $3-319 A-2-1,26-30$-artificially fluxed glass; $4-319 A-2-1,30-$ natural glass; 5-319A-2-2, 4-7-artificially fluxed glass; $11-319 \mathrm{~A}-6-1,77-78$-artificially fluxed glass; 14-320B-3-1, 101-105-natural glass; 15a-320B-5-1, 127-131-natural glass; $15 \mathrm{~b}-$ As $15 \mathrm{a}$ but artificially fluxed; $20-321-14-4,20-23$-artificially fluxed glass.

aAll analyses by M. I. T. microprobe.

$\mathrm{b}_{\mathrm{O}} \mathrm{n}$ a volatile-free basis (i.e., after ignition).

cTotal iron as $\mathrm{FeO}$. 
TABLE 6

Trace Element Composition of DSDP Leg 34 Basalts (ppm, except $\mathrm{H}_{2} \mathrm{O}$ and $\mathrm{CO}_{2}$ in wt \%)

\begin{tabular}{|c|c|c|c|c|c|c|c|c|c|c|c|c|c|c|c|c|c|c|c|c|}
\hline & \multicolumn{4}{|c|}{ Group I } & \multicolumn{8}{|c|}{ Group II } & \multicolumn{2}{|c|}{ Group III } & \multirow{2}{*}{$\begin{array}{c}\text { Group IV } \\
15 \\
\end{array}$} & \multicolumn{5}{|c|}{ Group V } \\
\hline & 1 & 2 & 3 & 4 & 5 & 6 & 7 & 8 & 9 & 10 & 11 & 12 & 13 & 14 & & 16 & 17 & 18 & 19 & 20 \\
\hline \multicolumn{21}{|l|}{ Set I } \\
\hline $\mathrm{H}_{2} \mathrm{O}$ & 1.16 & 1.79 & 0.89 & 1.52 & 1.34 & 1.25 & 1.25 & 1.34 & 1.97 & 2.41 & 2.23 & 2.15 & 2.86 & 0.98 & 0.89 & 1.70 & 0.89 & 0.98 & 1.70 & 1.70 \\
\hline $\mathrm{CO}_{2}$ & 0.62 & 0.95 & 0.40 & 1.72 & 0.26 & 0.18 & 0.37 & 0.40 & 0.62 & 2.75 & 1.50 & 0.48 & 0.33 & 0.29 & 0.37 & 0.48 & 0.33 & 0.95 & 1.50 & 0.11 \\
\hline $\mathrm{Fe}_{2} \mathrm{O}_{3} / \mathrm{FeO}$ & 0.45 & & 0.37 & & 0.68 & & & & & & 0.86 & & & 0.27 & 0.37 & & & & & 0.44 \\
\hline B & 16 & 9 & 9 & $<2$ & $<2$ & 36 & $<2$ & $<2$ & 3 & 4 & 2 & 8 & 6 & 3 & $<2$ & 8 & $<2$ & $<2$ & 46 & $<2$ \\
\hline $\mathrm{Li}$ & 5 & 18 & 5 & 5 & 13 & 10 & 9 & 10 & 9 & 7 & 20 & 35 & 35 & 7 & 7 & 9 & 8 & 8 & 10 & 8 \\
\hline \multicolumn{21}{|l|}{ Set II } \\
\hline $\mathrm{Sc}$ & 50.1 & 50.8 & 44.7 & 50.2 & 48.6 & & & 46.8 & & 46.7 & 46.8 & & & 42.9 & 49.8 & & & 46.9 & & 53.0 \\
\hline V & 265 & 255 & 260 & 265 & 355 & 355 & 365 & 340 & 330 & 335 & 350 & 325 & 300 & 260 & 390 & 420 & 425 & 430 & 435 & 445 \\
\hline $\mathrm{Cr}$ & 245 & 250 & 255 & 250 & 220 & 225 & 220 & 215 & 195 & 235 & 245 & 240 & 360 & 335 & 110 & 120 & 105 & 105 & 115 & 115 \\
\hline $\mathrm{Co}$ & 49 & 49 & 44 & 52 & 45 & 38 & 45 & 48 & 45 & 41 & 54 & 41 & 42 & 48 & 45 & 40 & 49 & 45 & 43 & 43 \\
\hline $\mathrm{Ni}$ & 80 & 95 & 70 & 80 & 75 & 65 & 85 & 85 & 90 & 75 & 170 & 60 & 87 & 120 & 60 & 60 & 80 & 65 & 60 & 65 \\
\hline $\mathrm{Cu}$ & 105 & 75 & 100 & 85 & 55 & 35 & 65 & 65 & 65 & 65 & 65 & 65 & 70 & 75 & 55 & 40 & 55 & 50 & 55 & 60 \\
\hline $\mathrm{Ga}$ & 15 & 16 & 17 & 16 & 19 & 19 & 20 & 19 & 18 & 18 & 18 & 18 & 17 & 16 & 20 & 21 & 20 & 19 & 21 & 20 \\
\hline \multicolumn{21}{|l|}{ Set IIIA } \\
\hline $\mathrm{Sr}$ & 85 & 85 & 95 & 115 & 100 & 105 & 110 & 115 & 130 & 95 & 105 & 125 & 100 & 110 & 95 & 85 & 75 & 85 & 85 & 80 \\
\hline $\mathrm{Ba}$ & 2 & 6 & $<2$ & 3 & 3 & 3 & 2 & 3 & 3 & $<2$ & 16 & 4 & 2 & 7 & 5 & 12 & 12 & 12 & 9 & 10 \\
\hline $\mathrm{Y}$ & 35 & 30 & 31 & 38 & 52 & 55 & 55 & 60 & 55 & 50 & 55 & 52 & 40 & 38 & 60 & 70 & 65 & 68 & 60 & 60 \\
\hline $\mathrm{Zr}$ & 90 & 80 & 75 & 80 & 155 & 160 & 150 & 155 & 150 & 140 & 150 & 140 & 125 & 110 & 160 & 200 & 180 & 185 & 150 & 175 \\
\hline $\mathrm{Hf}$ & 2.1 & 2.0 & 1.7 & 2.1 & 3.4 & & & 3.0 & & 3.6 & 3.3 & & & 2.9 & 3.9 & & & 4.0 & & 4.9 \\
\hline \multicolumn{21}{|l|}{ Set IIIB } \\
\hline $\mathrm{La}$ & 1.76 & 1.77 & 1.67 & 1.89 & 3.72 & & & 3.48 & & 3.40 & 3.31 & & & 2.95 & 3.71 & & & 5.48 & & 5.14 \\
\hline $\mathrm{Ce}$ & 7.3 & 4.9 & 5.4 & 5.6 & 10.9 & & & 11.1 & & 10.7 & 10.4 & & & 9.1 & 13.2 & & & 16.3 & & 15.8 \\
\hline Nd & 7.4 & 6.0 & 6.3 & 7.2 & 11.9 & & & 12.2 & & 11.5 & 11.3 & & & 9.1 & 12.4 & & & 15.9 & & 14.5 \\
\hline $\mathrm{Sm}$ & 2.86 & 2.56 & 2.39 & 3.02 & 4.33 & & & 4.35 & & 4.05 & 4.25 & & & 3.30 & 4.70 & & & 5.16 & & 5.32 \\
\hline $\mathrm{Eu}$ & 1.04 & 0.90 & 0.88 & 0.97 & 1.47 & & & 1.49 & & 1.42 & 1.40 & & & 1.11 & 1.63 & & & 1.70 & & 1.72 \\
\hline $\mathrm{Tb}$ & & 0.61 & & 0.78 & & & & 0.85 & & 0.88 & & & & 0.72 & & & & 1.13 & & \\
\hline Ho & 1.05 & 0.94 & 1.03 & 1.09 & 1.61 & & & 1.52 & & 1.35 & 1.62 & & & 1.11 & 1.68 & & & 1.85 & & 1.80 \\
\hline $\mathrm{Yb}$ & 2.57 & 2.65 & 2.38 & 2.91 & 4.14 & & & 4.10 & & 3.91 & 3.82 & & & 3.42 & 4.70 & & & 5.38 & & 5.27 \\
\hline $\mathrm{Lu}$ & 0.48 & 0.50 & 0.46 & 0.49 & 0.74 & & & 0.68 & & 0.67 & 0.69 & & & 0.52 & 0.79 & & & 0.88 & & 0.88 \\
\hline
\end{tabular}


TABLE 7

Comparative Analyses of Reported East Pacific Rise Basalts, Average Leg 34

Basaltic Groups, and Other Reported Ocean Ridge Average Basalt Analyses

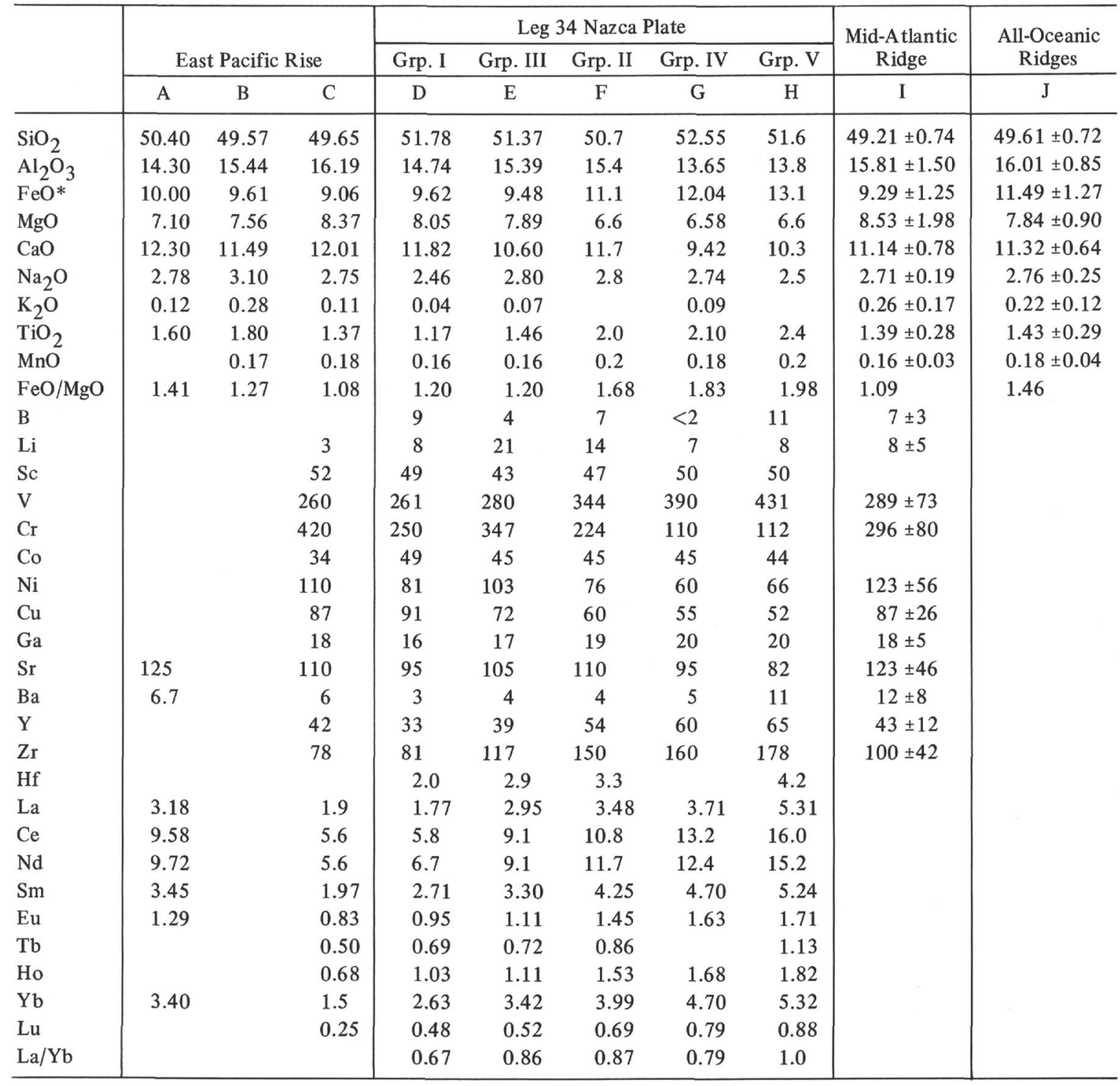

Note: A-Kay et al., 1970; B-Bonatti, 1968; C-Engel et al., 1965; REE data from Balashov et al., 1970; D-Average of Samples 1, 3, and 4 (Table 5) and 1,2,3, and 4 (Table 6);E-Sample 14 (Table 5) and average of 13 and 14 (Table 6); F-Average of Samples 5 and 11 (Table 5) and Samples 5-12 (Table 6); G-Sample 15a (Table 5) and 15 (Table 6); $\mathrm{H}$-Sample 20 (Table 5) and average of 16-20 (Table 6); I-Average of 33 basalts, Melson et al., 1968; J-Average of 94 basalts, Cann, 1971.

ocean ridge basalts (Miyashiro et al., 1969; Frey et al., 1974), they are on or close to a plagioclase-pyroxene cotectic.

In Figure 4(B) we have plotted the chondrite-normalized REE abundances for the Leg 34 basalt groups. There is a systematic difference in overall REE abundance between the groups. Although light REE depletion relative to chondrites is seen in all groups, it is less in the more evolved basalts, e.g., the $\mathrm{La} / \mathrm{Yb}$ changes from 0.68 in the Group I basalts to 1.0 in the Group V basalts. A corresponding systematic difference is also seen in major element compositions. The average compositions of each group are given in Table 7 and are plotted, relative to the Group I basalts, in Figure 5. A sequence of increasing concentration of $\mathrm{K}, \mathrm{Ti}, \mathrm{Fe}$, and decreasing $\mathrm{Mg}$ concentration is noted in the order Group I to III to II to IV then V. This is the same order as the increasing REE in Figure 4. Other trace element concentrations show almost the same trends between the groups. The average compositions are given in Table 7 and are plotted, relative to Group I concentrations, in Figure 6. Increasing concentrations of $\mathrm{V}, \mathrm{Ba}, \mathrm{Y}, \mathrm{Zr}, \mathrm{Hf}$, and $\mathrm{La}$ are systematic from Group I to III to II to IV to $\mathrm{V}$. The changes in $\mathrm{Cr}$ and $\mathrm{Ni}$ are not as marked as is often found in fractionated sea-floor basalts (Thompson et al., 1972; Frey et al., 1974) presumably because in the Leg 34 basalts the fractionation is not dominated by olivine. Also $\mathrm{Cr}$ and $\mathrm{Ni}$ concentrations are slightly 

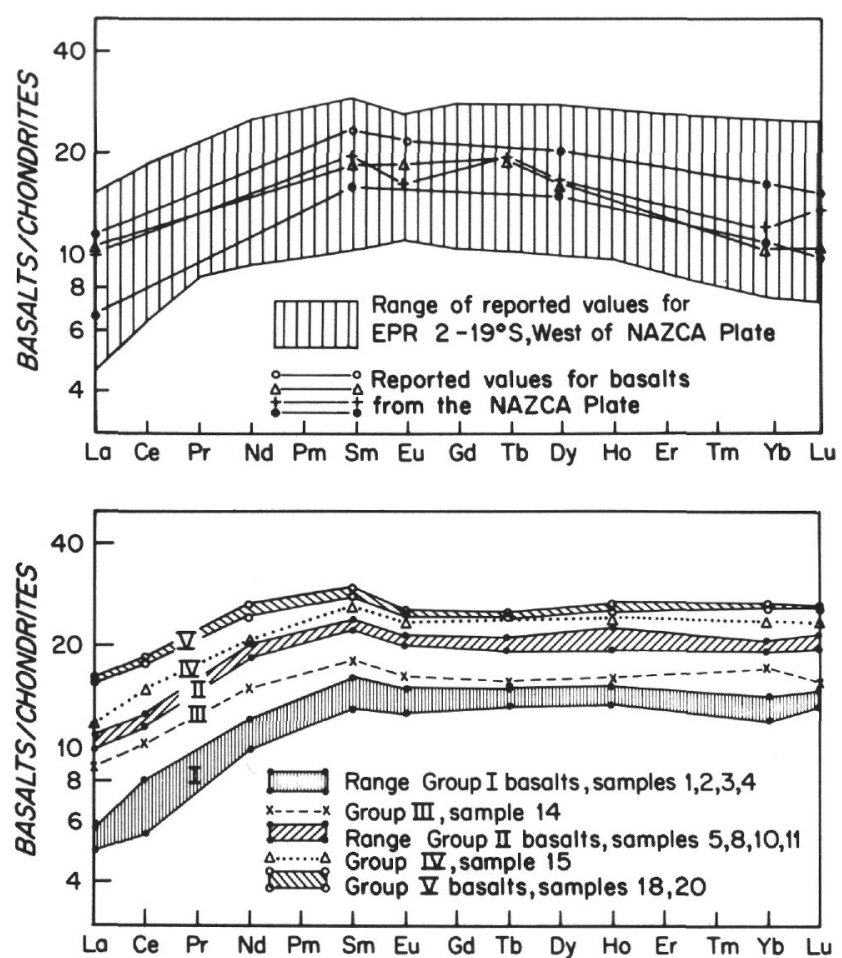

Figure 4. (A) Rare earth element distributions, relative to chrondites, for reported East Pacific Rise and Nazca plate basalts. (B) Rare earth element distributions, relative to chondrites, for different basalt groups in Leg 34 samples.

higher in the Group III basalts than in Group I. Group $\mathrm{V}$ basalts from Site 321 are comparable to other seafloor basalts which have been suggested to be highly evolved liquids developed during extensive fractional crystallization of a basaltic magma (Table 8).

The systematic major and trace element trends (Figures 4, 5, and 6; Tables 5 and 6) of the Leg 34 basalt groups lead us to suggest that these basalts have different extents of fractional crystallization from parents of very similar composition. As a preliminary and partial examination of these inferences, we have tested a simple linear model (Bryan, 1968) which forces a fit for $\mathrm{Al}_{2} \mathrm{O}_{3}, \mathrm{FeO}, \mathrm{MgO}$ and $\mathrm{CaO}$, the oxides which should be most sensitive to plagioclase, augite, and olivine crystallization. If our interpretation is correct, the basalt glass of Group IV should be a residual liquid formed by fractional crystallization from a liquid of Group I composition. Since the postulated Group I parent liquid apparently lies close to a pyroxene-plagioclase cotectic, the fractional crystallization process yielding the postulated residual Group IV liquid should be dominated by augite and plagioclase in about equal proportions with little or no olivine.

The results (Table 9) indicate that except for $\mathrm{K}_{2} \mathrm{O}$ and $\mathrm{TiO}_{2}$ all major elements can be fit to better than $\pm 5 \%$ by $36 \%$ crystallization of a cumulate involving principally plagioclase and augite. The increase in $\mathrm{La} / \mathrm{Yb}$ with increasing fractionation (e.g., Group I La/Yb $=0.6$ to Group IV $\mathrm{La} / \mathrm{Yb}=0.8$ ) is consistent with clinopyroxene as a prominent fractionation phase. At low
TABLE 8

Comparative Analyses of Primitive and Fractionated Oceanic Basalts, and Sites 319 and 321 Basalts

\begin{tabular}{|c|c|c|c|c|}
\hline & A & B & C & D \\
\hline $\mathrm{SiO}_{2}$ & 50.0 & 52.16 & 51.0 & 51.6 \\
\hline $\mathrm{Al}_{2} \mathrm{O}_{3}$ & 17.4 & 14.51 & 13.5 & 13.8 \\
\hline $\mathrm{FeO}^{*}$ & 8.22 & 9.66 & 11.3 & 13.1 \\
\hline $\mathrm{MgO}$ & 9.81 & 8.03 & 6.68 & 6.6 \\
\hline $\mathrm{CaO}$ & 12.9 & 11.38 & 10.9 & 10.3 \\
\hline $\mathrm{Na}_{2} \mathrm{O}$ & 3.30 & 2.48 & 3.30 & 2.5 \\
\hline $\mathrm{K}_{2} \mathrm{O}$ & 0.02 & 0.04 & 0.11 & - \\
\hline $\mathrm{TiO}_{2}$ & 0.79 & 1.16 & 2.20 & 2.4 \\
\hline $\mathrm{MnO}$ & 0.13 & 0.16 & 0.19 & 0.2 \\
\hline $\mathrm{FeO} / \mathrm{MgO}$ & 0.84 & 1.20 & 1.69 & 1.98 \\
\hline $\mathrm{Sc}$ & 39 & 51 & 44 & 47 \\
\hline V & 190 & 261 & 310 & 431 \\
\hline $\mathrm{Cr}$ & 900 & 250 & 240 & 112 \\
\hline Co & 50 & 49 & 35 & 44 \\
\hline $\mathrm{Ni}$ & 320 & 81 & 80 & 66 \\
\hline $\mathrm{Cu}$ & 130 & 91 & 95 & 52 \\
\hline $\mathrm{Ga}$ & 14 & 16 & 17 & 20 \\
\hline $\mathrm{Sr}$ & 52 & 95 & 125 & 82 \\
\hline $\mathrm{Ba}$ & $<5$ & 3 & 18 & 11 \\
\hline $\mathrm{Y}$ & 20 & 33 & 40 & 65 \\
\hline $\mathrm{Zr}$ & 35 & 81 & 150 & 178 \\
\hline Hf & 1.16 & 2.0 & 3.94 & 4.0 \\
\hline $\mathrm{La}$ & 1.0 & 1.77 & 4.1 & 5.31 \\
\hline $\mathrm{Sm}$ & 1.60 & 2.71 & 4.33 & 5.24 \\
\hline $\mathrm{Yb}$ & 2.66 & 2.63 & 3.85 & 5.32 \\
\hline
\end{tabular}

Note: A-DSDP, Leg 3 Site 14 Glass (Frey et al., 1974), primitive; B-Site 319 , Group I basalts, average; C-DSDP Leg 3, Site 15 glass (Frey et al., 1974), fractionated; D-Site 321, Group $\mathrm{V}$ basalts, average.

pressures clinopyroxene is the only major fractionating phase which can significantly increase $\mathrm{La} / \mathrm{Yb}$ in the residual liquid. Plagioclase fractionation causes a decrease in $\mathrm{La} / \mathrm{Yb}$, and olivine fractionation does not significantly affect the ratio because olivine has very low REE abundances. However, between Groups I and V several LIL-element ( $\mathrm{Ba}, \mathrm{Zr}, \mathrm{Hf}, \mathrm{La}$, and $\mathrm{Ce}$ ) abundances increase by a factor of two or more; such differences require separation of at least $50 \%$ or more of the magma as LIL-element poor phases such as plagioclase and pyroxene. Crystallization of $50 \%$ or more of low $\mathrm{K}_{2} \mathrm{O}$ and $\mathrm{TiO}_{2}$-bearing phases would also markedly improve the fit for $\mathrm{K}_{2} \mathrm{O}$ and $\mathrm{TiO}_{2}$. Approximately $50 \%$ removal of only clinopyroxene would be required to explain the $\mathrm{La} / \mathrm{Yb}$ increase in Group IV relative to Group I. Thus, there is a discrepancy between models accounting for major elements and the models necessary to explain LIL-element (including $\mathrm{K}_{2} \mathrm{O}$ and $\mathrm{TiO}_{2}$ ) abundances. We have noted similar discrepancies in modeling the chemical variations in DSDP Leg 2 and 3 basalts (Frey et al., 1974) as well as in other sea-floor basalts now under study. Hence, it seems unlikely that these discrepancies are purely a chance result of the selection of the Group I glass as an inferred parent. The implication is that, while shallow level fractional crystallization seems adequate to account for most major element 


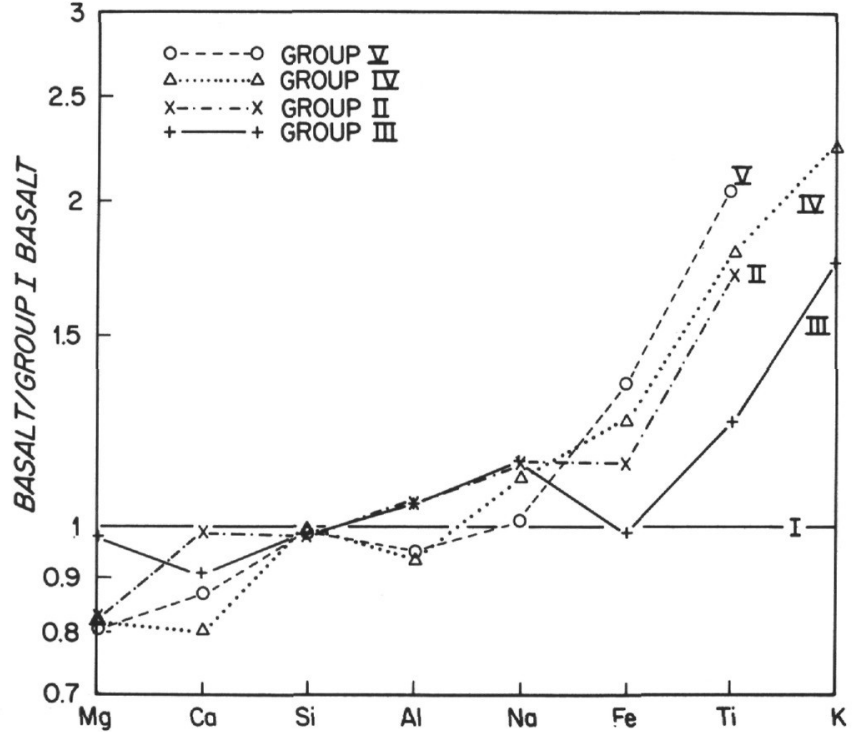

Figure 5. Major element distributions, relative to the Group I basalts, for other Leg 34 basalt groups.

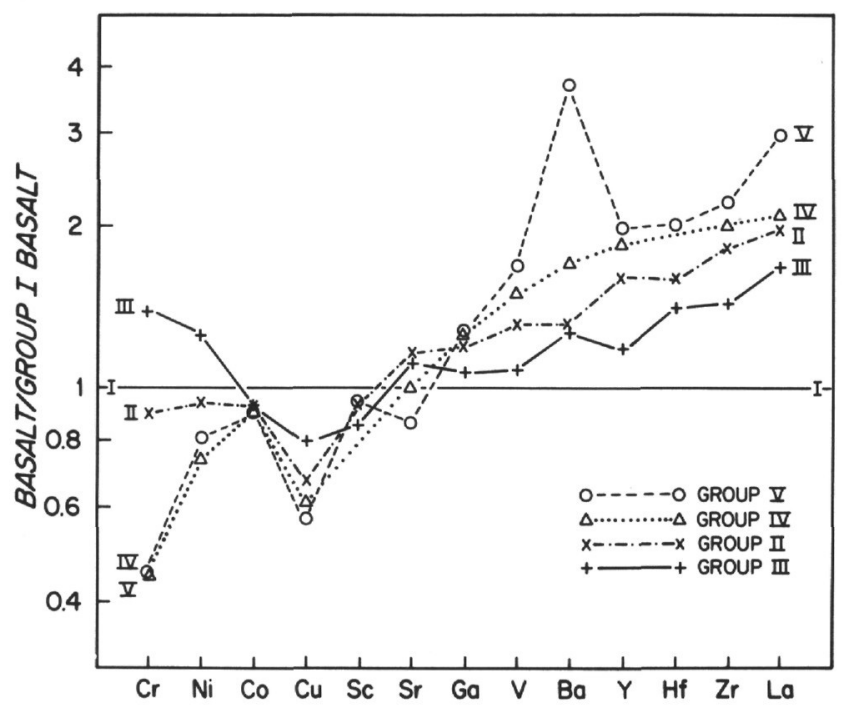

Figure 6. Trace element distributions, relative to the Group I basalts, for other Leg 34 basalt groups.

trends in the Leg 34 basalts, other processes must be responsible for the large differences in LIL-element (including $\mathrm{K}_{2} \mathrm{O}$ and $\mathrm{TiO}_{2}$ ) abundances. Apparently, the parental magmas had different LIL-element abundances; these differences were probably caused by different degrees of partial melting of the source materials and/or source rock heterogeneity.

In any event, the LIL element depleted characteristics of these basalts, and their similarity to other ridge basalts (particularly the East Pacific Rise basalts), are consistent with their evolution at a ridge crest or spreading center, and not as later off-ridge extrusions.

\section{ACKNOWLEDGMENTS}

We thank D.C. Bankston, J. Guertler, and A. Parks for help in the laboratory procedures. We gratefully acknowledge the
TABLE 9

Composition of Glass 1, Group I, Compared to Composition Calculated as a Linear Combination of Plagioclase, Augite, Olivine, and Glass 15a, Group IV

\begin{tabular}{lrr}
\hline & \multicolumn{1}{c}{$\mathrm{A}$} & \multicolumn{1}{c}{$\mathrm{B}$} \\
\hline $\mathrm{SiO}_{2}$ & 52.13 & 52.63 \\
$\mathrm{Al}_{2} \mathrm{O}_{3} \mathrm{a}$ & 14.49 & 14.49 \\
$\mathrm{FeO}^{\mathrm{a}}$ & 9.62 & 9.62 \\
$\mathrm{MgO}^{\mathrm{a}}$ & 8.07 & 8.07 \\
$\mathrm{CaO}^{\mathrm{a}}$ & 11.42 & 11.42 \\
$\mathrm{Na}_{2} \mathrm{O}$ & 2.49 & 2.59 \\
$\mathrm{~K}_{2} \mathrm{O}$ & 0.04 & 0.06 \\
$\mathrm{TiO}_{2}$ & 1.15 & 1.55 \\
$\mathrm{MnO}$ & 0.16 & 0.16
\end{tabular}

Note: A-Glass 1, Table 5; B-Composition calculated in terms of the following weight fractions: 0.636 glass $15 \mathrm{a}$, Table $5 ; 0.183$ plagioclase $\mathrm{D}$, Table $4 \mathrm{a} ; 0.167$ augite $\mathrm{A}$, Table $4 \mathrm{~b}$; 0.027 olivine $A$, Table $4 \mathrm{c}$.

${ }^{a}$ Oxide used in calculation.

support of this work by the Submarine Geology Branch of the National Science Foundation under Grants 41393 to Woods Hole Oceanographic Institution and 41403 to MIT.

This is Contribution No. 3506 from the Woods Hole Oceanographic Institution.

\section{REFERENCES}

Balashov, Yu. A., Dmitriev, L.V., and Sharaśkin, A.Ya., 1970. Distribution of the rare earths and yttrium in the bedrock of the ocean floor: Geochem. Internatl., v. 6, p. 456-468.

Bonatti, E., 1968. Fissure basalts and ocean floor spreading on the East Pacific Rise: Science, v. 161, p. 886-888.

Bryan, W.B., 1968. Materials balance in igneous rock suites: Carnegie Inst. Wash. Year Book, v. 67, p. 241-243.

1974. Sector-zoning and $\mathrm{Fe}-\mathrm{Mg}$ relationships in submarine basalt plagioclase: Earth Planet. Sci. Lett., v. 24, p. $157-165$.

Cann, J.R., 1971. Major element variations in ocean-floor basalts: Phil. Trans. Roy. Soc. London, Series A., v. 268, p. 495-505.

Engel, A.E.J., Engel, C.G., and Havens, R.G., 1965. Chemical characteristics of oceanic basalts and the upper mantle: Geol. Soc. Am. Bull., v. 76, p. 719-734.

Flanagan, F.J., 1972. 1972 values for international geochemical reference samples: Geochim. Cosmochim. Acta, v. 37, p. $1189-1200$.

Frey, F.A., Haskin, M.A., Poetz, J., and Haskin, L.A., 1968. Rare earth abundances in some basic rocks: J. Geophys. Res., v. 73, p. 6085-6098.

Frey, F.A., Bryan, W.B., and Thompson, G., 1974. Atlantic Ocean floor: geochemistry and petrology of basalts from Legs 2 and 3 of the Deep Sea Drilling Project: J. Geophys. Res., v. 79, p. 5507-5527.

Hart, S.R., 1969. K, Rb, Cs contents and K/Rb, K/Cs ratios of fresh and altered submarine basalts: Earth Planet. Sci. Lett., v. 6, p. 295-303.

Kay, R., Hubbard, N.J., and Gast, P.W., 1970. Chemical characteristics and origin of oceanic ridge volcanic rocks: J. Geophys. Res., v. 75, p. 1585-1613. 
Melson, W.G., Thompson, G., and Van Andel, Tj. H., 1968. Volcanism and metamorphism in the Mid-Atlantic Ridge, $22^{\circ}$ N latitude: J. Geophys. Res., v. 73, p. 5925-5941.

Miyashiro, A., Shido, F., and Ewing, M., 1969. Diversity and origin of abyssal tholeiite from the Mid-Atlantic Ridge near $24^{\circ}$ and $30^{\circ}$ north latitude: Contrib. Mineral. Petrol., v. 23 , p. $38-52$.

Reed, S.J.B., 1970. The analysis of rocks in the electron probe: Geochim. Cosmochim. Acta, v. 34, p. 416-421.
Schilling, J.G. and Bonatti, E., 1975. East Pacific Ridge $\left(2^{\circ} \mathrm{S}-\right.$ $19^{\circ} \mathrm{S}$ ) versus NAZCA interplate volcanism: rare earth evidence: Earth Planet. Sci. Lett., v. 25, p. 93-102.

Thompson, G., 1973. A geochemical study of the low-temperature interaction of sea-water and oceanic igneous rocks: EOS, v. 54, p. 1015-1018.

Thompson, G., Shido F., and Miyashiro, A., 1972. Trace element distributions in fractionated oceanic basalts: Chem. Geol., v. 9, p. 89-97. 